消化性潰瘍手術前後のペプシン分泌に関する研究

和歌山県立医科大学外科学講座(消化器)（指導：勝見正治教授）

大澤袏 三

\title{
STUDIES ON PEPSIN SECRETION BEFORE AND AFTER GASTRIC OPERATIONS IN PATIENTS WITH PEPTIC ULCER
}

\section{Yuzo OHSAWA}

Department of Surgery, (Gastroenterological Division), Wakayama Medical College

ペプシンは胃酸とほぼ同時期に発見されたにもかかからず，現在でもとの病因的意義は不明な点が多 い. 著者は胃液採取をより正確にするため, バルーン付き胃管を使用して, 各種消化性潰場手術前後にぺ プシン活性を測定し, 胃液酸度及びほぼ同時期に測定した, 空腹時血清ガストリン值, 胃内容排出時間と の関連より，ペプシン分泌に影響を及ぼす諸因子の究明につとめ，また消化性潰瘍の外科的治療のペプシ ン分泌対する効果を検討し，ペプシンは必ずしも酸と平行するものではなく，また消化性潰場ではペプ シンと空腹時血清ガストリン值は負の相関関係にあり, さらに胃潰瘍において, ペプシンと胃内容排出時 間は正の相関関係にあることが認められた。

索引用語：ベプシン, 胃酸, 血清ガストリン, 胃内容排出時間, バルーン付き胃管

\section{I緒 言}

胃内塩酸が Prout (1824) によって発見されてまむな く, ペプシンが Schwann (1836)により発見されだ). しかし塩酸の研究の発展に比べ, ペプシンの研究はその 測定法の煩雑さや，臨床的意義が明確でないことなどか ら大幅に遅れをとってきた。最近では抗ペプシン剤の登 場2)3445 の結果, 逆にペプンンの意義が見直され, 諸家 により報告が增加してきており，ペプシンが消化性潰瘍 発生過程における攻撃因子の主役を演じるものと考えら れるに至ったが，まだその病因的意義は完全に究明され たとはいい難い，そこで著者は消化性潰瘍の成因の一端 をさぐるべく, 胃液酸度, 血清ガストリン値, 胃内容排 出時間との関連から、ペプシン分泌影響を及ぼす諸因 子の究明につとめ, あわせて消化性潰瘍の外科的治療の ペプシン分泌に対する効果を検討した。

\section{II 研究対象および方法}

対象は胃潰愓（以下 GU）61例，十二指腸潰瘍（以下 DU) 56例，胃十二指腸 併存潰瘍 (以下 GDU) 13例, 胃癌 (以下 GC) 6 例, 正常 (以下 Control) 5 例の合 計141例で, その性別, 年龄分布 招よび 平均年齢は表 1
表 1 研究対象

\begin{tabular}{|c|c|c|c|c|}
\hline & 症例数 & 性別 & 年令分布 & 平均年令 \\
\hline  & 61 & $\stackrel{8}{8} 45$ & $27 \sim 73$ & 50.3 \\
\hline 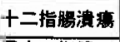 & 56 & $\stackrel{8}{82}$ & $11 \sim 68$ & 37.2 \\
\hline 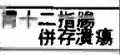 & 13 & $\begin{array}{l}11 \\
0 \\
\end{array}$ & $22 \sim 70$ & 43.2 \\
\hline 癌 & 6 & $\begin{array}{l}6 \\
\vdots \\
\end{array}$ & $29 \sim 72$ & 59.2 \\
\hline 正常 & 5 & & $26 \sim 68$ & 38.2 \\
\hline 計 & 141 & $\begin{array}{lll}5 & 117 \\
8 & 24\end{array}$ & $11 \sim 73$ & 44.4 \\
\hline
\end{tabular}

に示す.なお，後に述べる胃液採取法の検討のため，こ の症例之は別に前期症例は胃潰瘍31例であり，これを含 めると総合計は172例となる。

手術々式は DU には選択的近位迷走神経切離術単独 または Jaboulay 型幽門形成術の併用（以下 $\mathrm{SPV} \pm \mathrm{D}$ ) を，GU には教室で施行している幽門括約筋保存胃半切

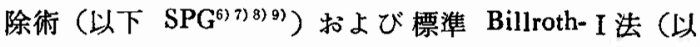
下 B - I ) を施行し, その各術式の症例について検討し た。

なお，胃液採取は従来の Rehfuss 管使用では不満足な ことも多く，より正確な胃液採取をはかるため, バルー 
ン付き胃管 ${ }^{10)}$ を使用し, 10 分間隔の分画的胃液採取法 で，刺激前30分間，刺激後120分間の計150分間，15回の 採取を行った。刺激剤はテトラガストリン $(4 \mu \mathrm{g} / \mathrm{kg}$ 筋 注, 以下 TG) とレギュラーインシュリン $(0.2 \mathrm{U} / \mathrm{kg}$ 静 注, 以下 RI) を用いた。 ペプシン活珄測定は日本消化 器病学会胃液測定法倹討委員会で定められた方法 ${ }^{11}$ に従 い，胃液酸度測定は Töpfer-Michaelis 法で行った。胃 液㭘查は術前と術後 I カ月, 3 力月に施行し, それとほ ぼ同時期に空腹時血清ガストリン值測定と胃内容排出機 能検查を施行した。前者はDinabot gastrin kit で測定し (単位 $\mathrm{pg} / \mathrm{ml}$ ) 後者は教室の谷口らの Gastroscintigram 12)13) で測定し Half Gastric Emptying Time (T $1 / 2$, 単 位 min. 以下 GET) を胃内容排出時間の代表値として 用いた。

各表現法は以下の通りとした。

BSVR：基碟胃液分 泌量, MSVR：最大刺激胃液分泌 量, PSVR：最高刺激胃液分泌量（以上いずれる単位は $\mathrm{ml} / \mathrm{h})$ ，ペプシン分泌の表現は全て胃酸に準じた方法で 表現した. BPO : 基礎ペプシン分泌量, MPO : 最大刺 激ペプシン分泌量, PPO : 最高刺激ペプシン分泌量 (以 上いずれも単位は $\mathrm{mg} / \mathrm{ml}$ ), BPA：基礎ペプシン活性 (単位は $\mu \mathrm{g} / \mathrm{ml}$ )

\section{III 軺 果}

1. バルーン付き胃管と従来の胃管との胃液採取量の 比較

非切除胃での胃液採取は瀬田ら ${ }^{10)}$ の方法で行ったが, 胃切除後の残胃では著者が透視下で検查した結果，噴門 部よりの㨂入距離を $4 \mathrm{~cm}$ にすると，ほぼ全量に近いバ リウムが回収されたので，残胃ではこの方法で行った （写真1），そこで手術を受けていない胃之胃切除後の残 胃に括いて，バルーン付き胃管と従来の胃管との胃液採 取量を比較した。対象を従来の胃管を使用していた昭和 46年〜昭和 48 年（前期）とバルーン付き胃管を使用した 昭和 51 年 昭和 54 年（後期）の二期に分け，手術を受け ていない胃として GU；切除後残胃として SPG につい て検討した（図门）.

BSVR, MSVR, PSVR について検討すると, 推計学的 には SPG の PSVR に $\mathrm{p}<0.02$ で有意差を諗めるにと どまったが，GU，SPG いずれにおいてすバルーン付き 胃管の方が胃液採取量が多く，また従来の胃管では GU で前述 3 項目に延べ 7 例, SPG で延べ 7 例に胃液採取 量 $\mathrm{Oml} / \mathrm{h}$ の症例があったのに対し, バルーン付き胃管 では $0 \mathrm{ml} / \mathrm{h}$ の症例はなかった。
写真 1 胃切後残胃へのハハルーン付き胃管の㨉入

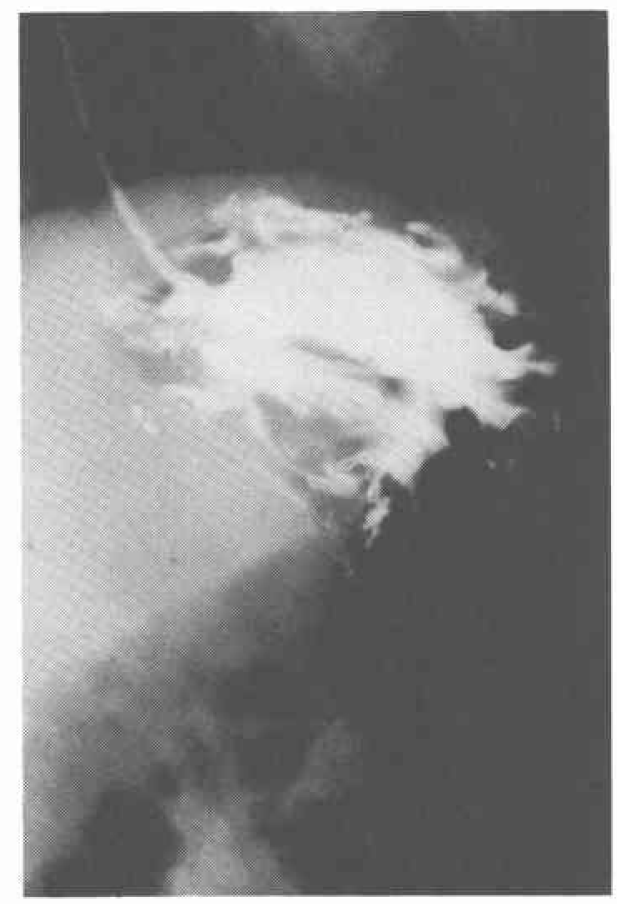

因 1 バルーン付き胃管と従来の胃管との胃夜 採取量の比較

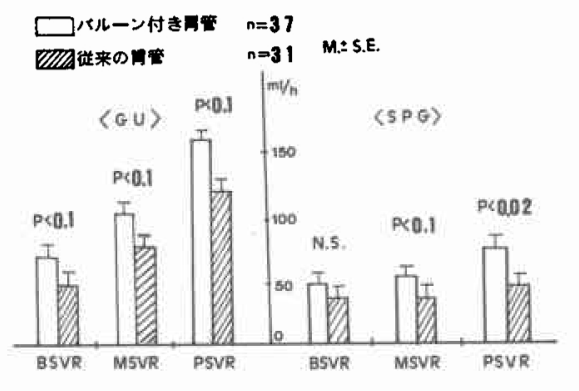

2. ペプシンと酸の関係

1）疾患別ペプシン分泌量について（図2）

i ) TG 刺激の場合

GDU と DU は有意差なし (以下 N.S.). GDU と GU はBPO と MPO で GDU が高い $(\mathrm{p}<0.01)$. DU と GU は BPO では DU が高い $(\mathbf{p}<0.01)$ が, 刺激後分 泌では N.S. である. 各潰愓と Control あるいは GC は N.S. であるが，これは Control あるいは GC の症例数 が少ないためであるらと考えられ，值は潰場群が明らか に高い。 
四2 疾患別ペプシン分泌量
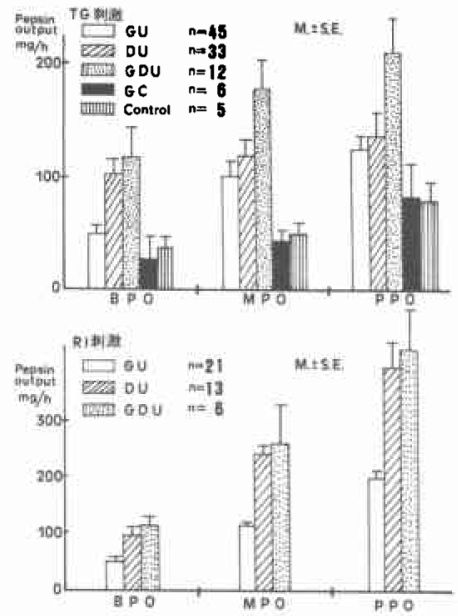

図 3 疾患別酸分泌量
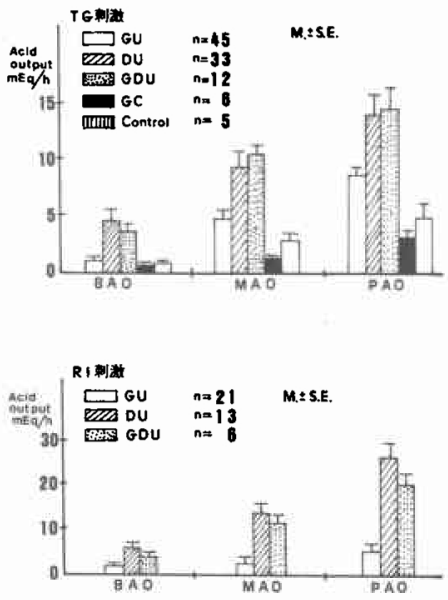

ii ) RI 刺激の場合

GDU と DU は N.S.. GDU と GU は BPO とPPO で GDU が高い $(\mathrm{p}<0.01, \mathrm{p}<0.05)$. DU と GU は BPO, MPO, PPO のいずれも DU が高い $(\mathrm{p}<0.01)$.

2）疾患別酸分泌量について（図3）

i ) TG 刺激の場合

GDU と DU は N.S.. GDU と GU は BAO, MAO, PAO のいずれ \& GDU が高い $(\mathrm{p}<0.01, \mathrm{p}<0.01$, $\mathrm{p}<0.05)$. DU と GU は BAO, MAO, PAO のいずれ も DU が高い $(\mathrm{p}<0.001, \mathrm{p}<0.02, \mathrm{p}<0.05)$. DU と Control では DU が高いが，これは1)と同様の理由で N.S. である.

ii ) RI 刺激の場合
GDU と DU は N.S.. GDU と GU は BAO, MAO, PAO のいずれも GDU が高い $(\mathrm{p}<0.01, \mathrm{p}<0.05$, $\mathrm{p}<0.02)$. DU と GU は $\mathrm{BAO}, \mathrm{PAO}$ のいずれる $\mathrm{DU}$ が高い $(\mathrm{p}<0.001, \mathrm{p}<0.02, \mathrm{p}<0.05)$.

以上より，TG 刺激の場合，ペプシン分泌量と酸分泌 量はよく似たパターンを示しているが，DU と GU を 比較するとぺプシン分化量では MPO, PPO でN.S. で あるのに対し，酸分化量では DU が GUより高い。ま た RI 刺激の場合，ペブシン分泌量では GDU が DU より高い傾向にあるのに比べ，酸分泌量では逆の傾向が 見られる。

3）消化珄潰昜におけるペプシン分泌量と酸分泌量の 関係について

i ) TG 刺激の場合（図 4)

GU 45例，DU 33例，GDU 12例の計90例について検 討すると, $\mathrm{BPO} と \mathrm{BAO}, \mathrm{MPO} と \mathrm{MAO}, \mathrm{PPO} と$ PAO の関俰はそれぞれ正の相関々係 $(\mathrm{p}<0.001, \mathrm{p}<$ $0.001 ， \mathrm{p}<0.001)$ が諗められる。

ii ) RI 刺激の場合 (図 5 )

GU 13例, DU 21例, GDU 6 例の計40例について検 討してみると, $\mathrm{BPO} と \mathrm{BAO}, \mathrm{MPO}$ と $\mathrm{MAO}, \mathrm{PPO}$ と

図4 消化性潰檫におけるペプシン分泌量と酸分泌 量の相関関係

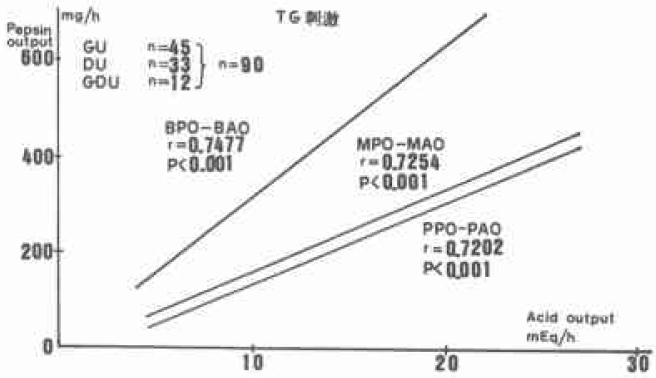

困 5 消化性潰湯におけるペプシン分泌量と酸分泌 量の相関関係

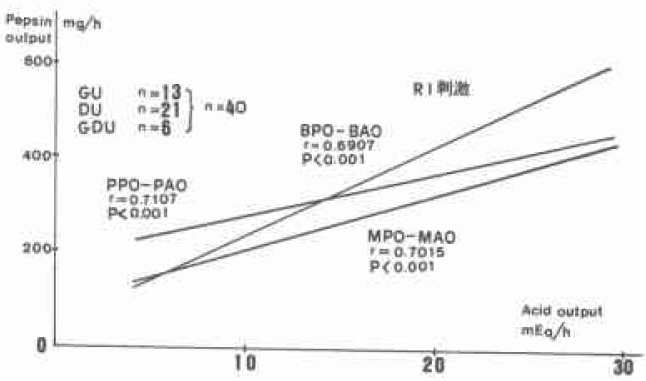


PAO の関係はそれぞれ正の相関々係 $(\mathrm{p}<0.001, \mathrm{p}<$ $0.001, \mathrm{p}<0.001)$ が認められる.

以上の結果, 消化性潰瘍に扣けるペプシン分泌量と酸 分泌量は基礎分泌，刺激後分泌のいずれも正の相関々係 が認められることがわかる。

4）消化性潰瘍手術後にお忷るペプシン分泌量と酸分 泌量の関係について

i ) TG 刺激の場合 (図6)

術後胃として胃切除例は SPG 17例，非胃切除例は $\mathrm{SPV} \pm \mathrm{D}$ 15例について，術式別に検討すると，SPGで は $\mathrm{BPO} と \mathrm{BAO}, \mathrm{MPO} \succsim \mathrm{MAO}, \mathrm{PPO}$ ¿ $\mathrm{PAO} て ゙$ それぞれ全て正の相関々係 $(\mathrm{p}<0.01, \mathrm{p}<0.001, \mathrm{p}<$ 0.001) が認められ，SPV $\pm \mathrm{D}$ に打いてもそれぞれ全て 正の相関々係 $(\mathrm{p}<0.01, \mathrm{p}<0.01, \mathrm{p}<0.001)$ が認めら れる。

図6 消化性潰湯手術後におけるペブシン分泌量と 酸分泌量の相関関係

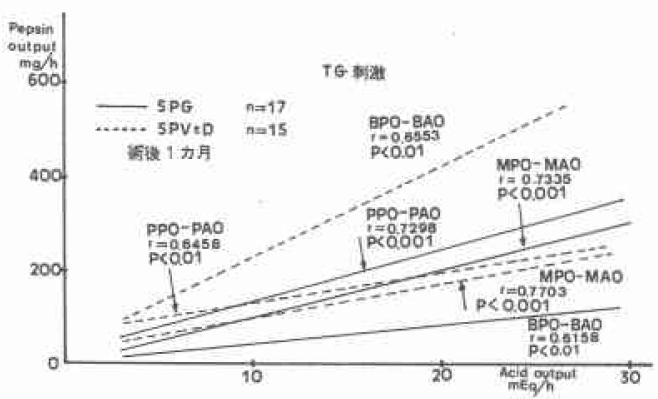

図 7 消化性潰瘍手術後におけるプペシン分泌量と 酸分泌量の相関関係

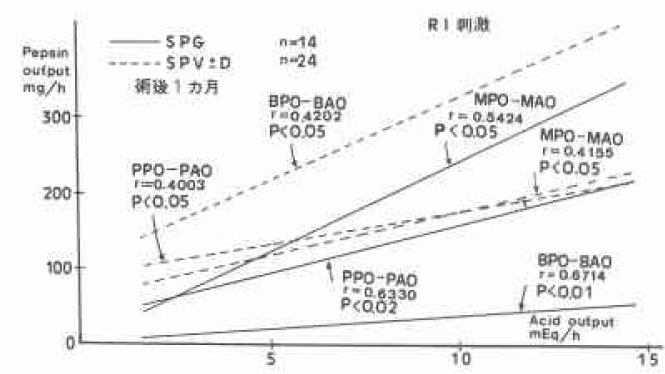

ii) RI 刺激の場合 (図 7)

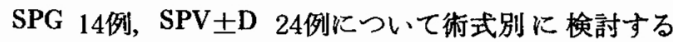
と, $\mathrm{SPG}$ では $\mathrm{BPO}$ と $\mathrm{BAO}, \mathrm{MPO}$ とAO, $\mathrm{PPO}$ と PAO でそれぞれ全て正の相関々係（p<0.01，p<0.05， $\mathrm{p}<0.02)$ が認められ，SPV士Dに扣いてもそれぞれ全
て正の相関々係 $(\mathrm{p}<0.05, \mathrm{p}<0.05, \mathrm{p}<0.05)$ が認め られる。

以上より，TG 刺激では胃切除或は迷走神経切離を 加えても，術前同様の相関々係が認められている。しか し RI 刺激では相関々係は認められるが，危険率は高 くなり，かつ相関々係を示す直線の勾配が術前と異な り，低くなる傾向が認められる。

5）DUに护る SPV 前後のペプシン活性につい $\tau$.

刺激前後の15分画について，ペプシン活性を検討す る.

i ) TG 刺激の場合 (図 8)

DU 33例, SPV \pm D 24例（但し SPV と SPV+D は N.S. であるため SPV士D として扱う)に拉いては, 術前は刺激前と比べ刺激後は上昇傾向は認めるが，有意 な上昇は認めない。また術後は刺激前に比べ，刺激後は

図 8 十二指腸潰場手術前後のペプシン活性 T G 蜼

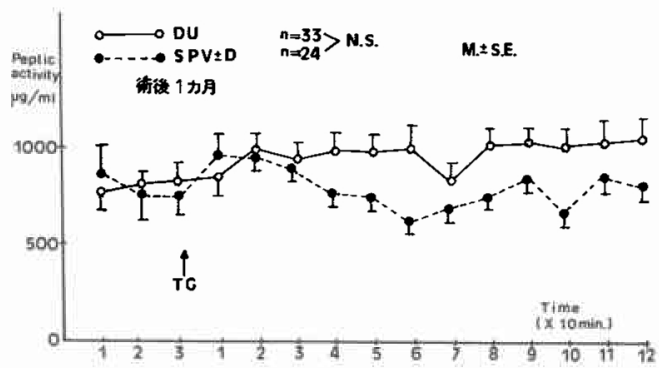

困 9 十二指腸潰浯手術前後のペプシン活性

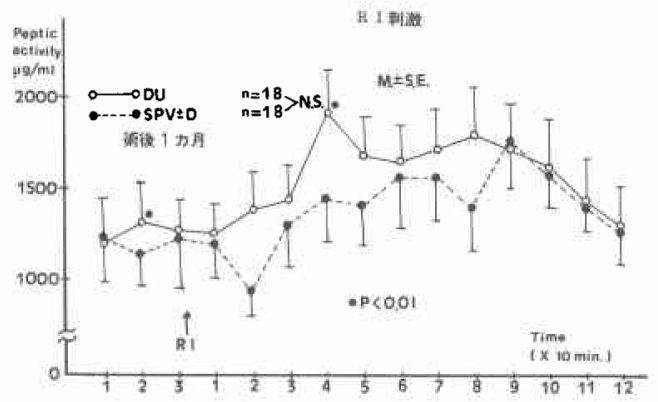

有意な上昇や低下は認められず，術後は術前に比べ，低 下傾向はあるが，有意な低下は認められない。

ii ) RI 刺邀の場合 (図9)

DU 18例，SPV土D 18例（但しi）と同様の理由で $\mathrm{SPV} \pm \mathrm{D}$ とて扱う）に拈いては，術前では刺激前值と 
刺激後最高值（刺激後40分）を比べると，明らかに刺激 後上昇 $(\mathrm{p}<0.01)$ L， RI によりペプシン活性は明ら かに刺激を受けていることが認められるまた術後では 刺激前值と刺敨後最高值（刺激後90分）を比べると有意 な上昇は認められない。さらに術後は術前に比べ各分画 で低下傾向は認められるが，N.S. である.

6）DUに拈ける SPV 前後の酸度について

i ) TG 刺激の場合 (図10)

術前では刺激前値と刺激後最高值 (刺激後50分)を比 ベると，明らかと刺激後上昇 $(p<0.001)$ ，術後は刺 激後40分で有意な上昇（ $\mathrm{p}<0.001 ）$ を示している．また 術後は各分画とも術前に比へ，低下傾向にあるが，N.S. である。

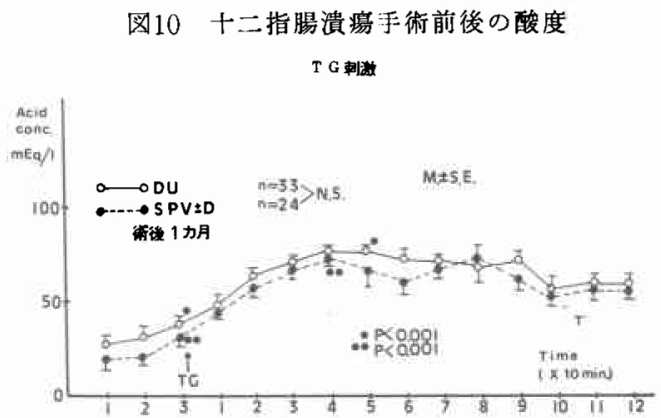

図11 十二指腸潰瘍手術前後の酸度 R I 刺激

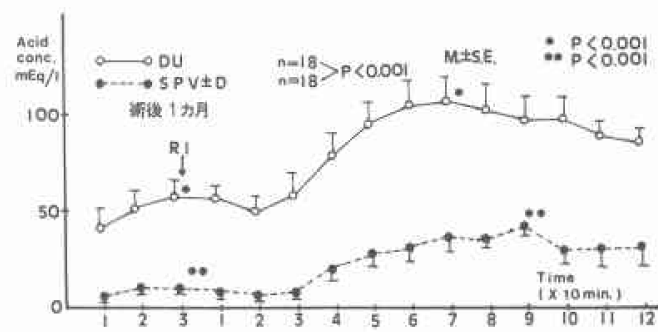

ii） RI 刺激の場合（図11）

刺激前值と刺激後最高值（刺激後70分）を比べると， 明らかに刺激後上昇し $(\mathbf{p}<0.001)$, 術後子同様飞上昇 する（刺激後90分， $\mathrm{p}<0.001$ ) が, 術後は術前に比べ全 分画を通じて有意任下 $(\mathrm{p}<0.001)$ する.

以上の結果，DU に执いては TG 刺激の場合, ペプ シン活性は，著明な上昇を示さないのに対し，酸度は有 意な上昇を示し，明らかにその刺激後のパターンが違う ことが認められる. RI 刺激の場合, ペプシン活性は最
高ペプシン活性を示すのに刺後 40 分を要し， $49 \%$ の上 昇であるのに比へ，酸度は最高酸度を示すのに刺激後 70 分を要しているが，94\%の上昇を示している，すなわち RI 刺激によりペプシン活性と酸度はともに有意な上昇 を示すが，刺敫に対する反応の速さはペプシン活性の方 がまさり，反応の程度は酸度の方がまさっていることを 示している.一方 SPV 後は両刺激剤によりペプシン活 性と酸度はともに減少傾向を示すが，有意な低下は RI 刺激での酸度のみである。

7）SPV 後のペプシン分泌量と酸分泌量について(因 12)

$\mathrm{SPV}$ \&PV+D はペプシン分泌量と酸分泌量につい て検討したが，N.S. であるため SPV $\pm D$ として扱う. TG 刺激24例, RI 刺激23例について刺激剂別倹討す る.

図12 SPV 後の刺剖別ペプシン分泌量と酸分泌量
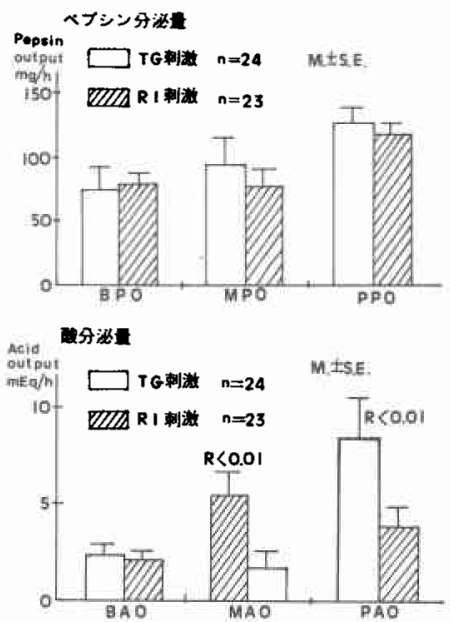

i ）ペプシン分泌量について

刺激後分泌量すなわち MPO, PPO では TG 刺激が やや高い傾向は見せているが，いずれもN.S. である.

ii）酸分泌量について

刺激後酸分泌量すなわち $\mathrm{MAO}, \mathrm{MPO}$ では TG 刺激 の方が有意に高い $(\mathrm{p}<0.01, \mathrm{p}<0.01)$.

以上の結果より, SPV 後のペプシン分泌量 と酸分泌 量は, ペプシン分泌量では両刺激風間に差がないのに対 し, 酸分泌量では RI 刺激の方が TG 刺激に比べ有意 に低く，迷走神経切離により，酸分泌に対する迷走神経 への刺激効果が少なくなっていることが認められる。

8） SPV 後の時間的経過によるペプシン分泌量と酸 
困13 SPV 後の時期別ペブシン分泌量と酸分泌量

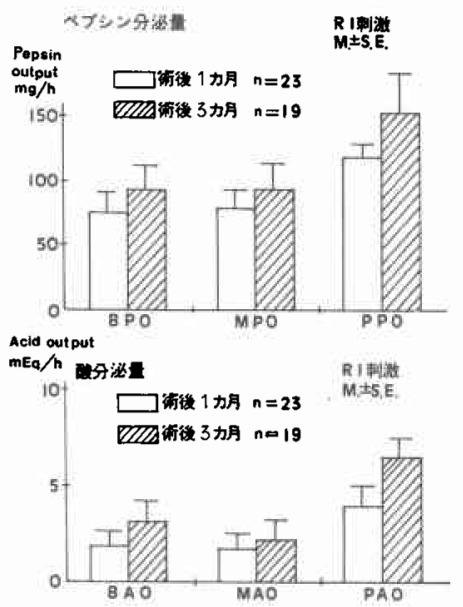

分泌量について (図13)

SPV 後 1 力月 23 例, 3 力月19例沈打いて, RI 刺激で のペプシン分泌量と酸分泌量について, 術後の時間的経 過の差についてみると，

i ）ペプシン分泌量について

BPO, MPO, PPO ともに術後 3 カ月の方が, 術後 1 カ月に比べ高い傾向は示すが, N.S. である.

ii ）酸分泌量について

$\mathrm{BAO}, \mathrm{MAO}, \mathrm{PAO}$ ともに術後 3 カ月の方が高い傾向 は示すが, N.S. である.

以上より, 術後 1 カ月と術後 3 力月との時間的経過に よるペプシン分泌量と酸分泌量の差は認められない.

9）GUにおけるペプシン分泌量と酸分泌量の術式別 比較について

i ）ペプシン分泌量について（図14）

TG 刺激についてみると，SPG 18例，B－Ｉ14例に捣い ては, MPO, PPO ではやや B-I の方が高い傾向は示 すが, N.S. である.RI 刺激についてみると, SPG 14 例，B－I 15例に拈いては，術式別にはN.S. である。

ii）酸分泌量について（図15）

TG 刺激についてみると, SPG 18例，B-I 14例にお いては, MAO, PAO ではやゃ SPG の方が高い傾向は 示すが，N.S.である. RI 刺激についてみると， SPG 14例，B－I 15例に括いては，B－Ｉが高い傾向は示すが， N.S. である.

以上より，SPG はB－I と比較するとペプシン分泌, 酸分泌いずれにおいても差がないことが認められる.

3. ペプシンと血清ガストリンの関係について(図16)
図14 SPG と B-I のペプシン分泌量
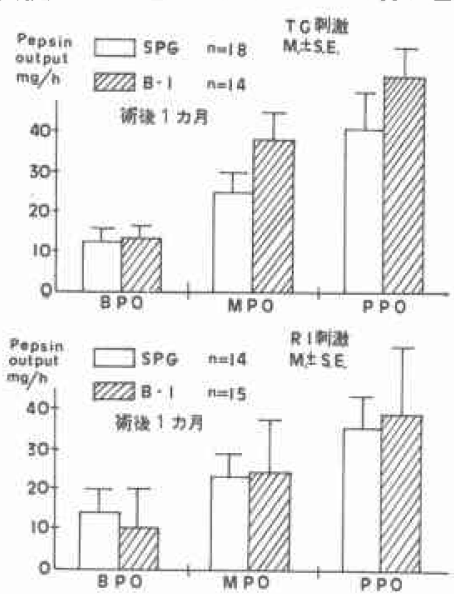

図15 SPG と B-I の酸分泌量

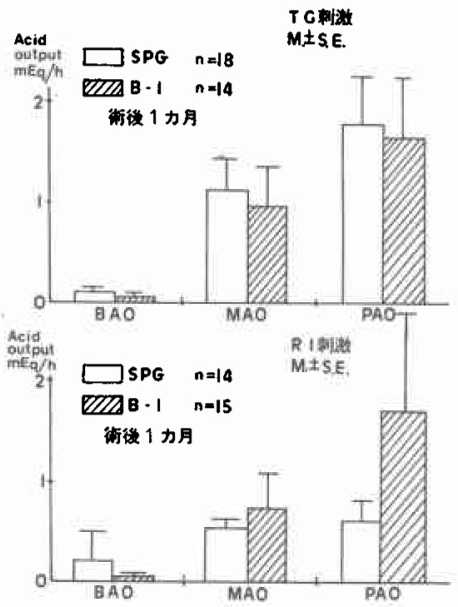

因16 消化性潰場の基礎ペプシン活性と空腹時血清 ガストリン值の相関関係

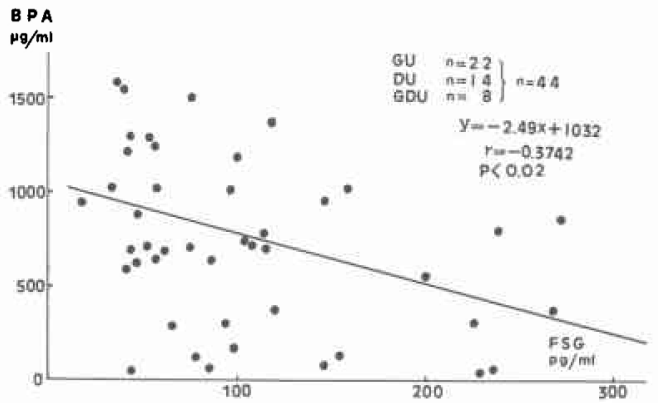


図17 胃潰晹のペプシン分泌量と GET (T 1/2) の 相関閔係

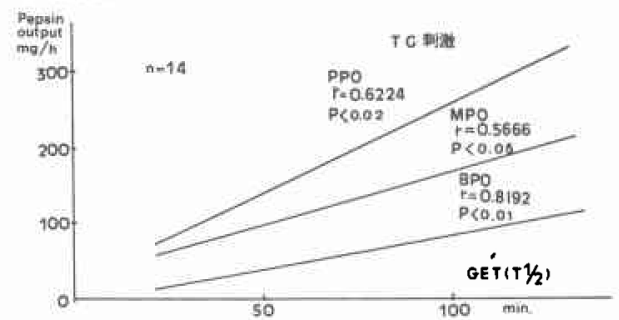

GU 22例, DU 14例, GDU 8 例の計44例について, BPA と空腹時血清ガストリン値 (以下 FSG) について, 相関々係を検討すると，負の相関々係 $(\mathrm{p}<0.02)$ が得 られ，FSG が高い程 BPA は低い(逆も同様)という 関係が得られた．尚基礎ペプシン分泌量と FSG につい ては相関々係は得られなかった。

4. ペプシンと胃内容排出時間との関係について（図 17)

GU 14例について, ペプシン分泌量と T 1/2の関係 を, TG 刺激によりみると, BPO, MPO, PPO のそれ ぞれと T 1/2は全て正の相関々倸 $(\mathrm{p}<0.01, \mathrm{p}<0.05$, $\mathrm{p}<0.02)$ が得られ, 胃内容排出時間が遅い程ペプシン 分泌量は増加し，しかもその相関々係を示す直線の勾配 が, PPO が最も高く, 以下 MPO, BPO の順になっ ている. 同様の関係を DU と GDU についても検討し たが，相関々係は得られない。

\section{IV 考祭}

ペプシンは胃内塩酸の発見より約10年後に Schwann $(1836)^{11}$ により発見され, 臨床的には Anson \& Mirsky $(1932)^{14)}$ によるペプシン活性測定法の発表以来, ペプシ ンに関する報告が増加し，胃酸同様の発展をとげるかに 思えたが，その測定法の煩雑さや，湘定条件が報告者に より異ったり，またこれらの方法と原理を異にする方法 などが入り混り，それぞれの報告者間の結果を比較検討 することがむづかしく，又一方ではペプシンが，消化性 潰瘍発生過程に挌ける重要な因子とされながらも，その 病因的意義が完全に究明されていないことなどからぺ プシン研究の低迷期が長かった。しかし1959年 Anderson ら゙の報告にはじまる抗ペプシン剤の登場により，その 潰瘍治療効果が，現在一応臨床的にも評価されるにいた り，またわが国においても1973年日本消化器病学会胃夜 測定法検討委員会によりペプシン測定法委員会試案が発 表されたのを期に，ペプシンに関する報告も増え，また
報告者相互の成績の比較検討る可能になり，ペプシンの 意義も徐々に解明しつつある. しかし潰瘍発生の病因的 意義はもちろんのこと, 治療的な意義に関しても不明な 点も多い、さらに外科的治療に括けるペプシンの意義は はなはだ不明な点が多い、本研究は外科的な面から, 現 在わが教室で消化性潰瘍の外科的治療の指釬としている 胃液酸度, 血清ガストリン值, 胃内容排出時間との関連 から, ペプシン分泌に影響を及ぼす諸因子の究明と, 迷 切術, 胃切術等の消化性潰瘍の外科的治療のペプシン分 泌に対する効果を検討した。

ペプシン，胃酸を測定する胃液検查では，まず胃液の 全量採取が必要条件である，従来胃液検查を施行する場 合, 胃液採取用の胃管として Rehfuss 管や Levine 管 が用いられ，デンデが歯列より55〜 60cm 入ったところ で胃液が出たならば，その位置で採取するといら方法 ${ }^{15)}$ で施行していたが，歯列より胃底部最下位への距離は個 人差がかなりあり，この方法で胃液採取を行うことは， 胃液の全量採取を目的としているこの検查では満足でき ないことも多い. 瀬田ら ${ }^{100}$ はこれらの欠点を補らため に, バルーン付き胃管を考按し，非切除胃での胃液の全 量採取が可能であるとしている ${ }^{16)}$.そこでわが教室でる この方法をとり入れ，胃液採取を行っているが，さらに 胃切除後残胃での胃液採取についても，バルーン付き胃 管で検討を加え，噴門よりバルーン付き胃管を $4 \mathrm{~cm}$ 挿 入することにより, 残胃においてもほぼ胃液全量の採取 が可能であることが確められた。これは非切除胃に拈け る噴門よりの㨀入距離 $7 \mathrm{~cm}$ と異なるむのであるが，こ れは胃切除術により残胃の胃穹隆部が変形するためと考 えられる。

ペプシンの研究の発展をさまたげていたものの1つ に, ペプシンと酸は平行するのであるから, ペプシンを 測定する必要はないのではないだろらかといら考方が あったと思われる.しかし近年各種刺激凧に対するぺプ シンと酸の反応が全く同じではないとの報告が見られ る.伊藤ら ${ }^{17)}$ はガストリン刺激により，ペプシン活性は 有意な上昇を示さず，胃液分泌量を考慮に入れた pepsin output で表現しても著明な上昇は認めないという.— 方胃酸分泌は有意な上昇を示し，むしろペプシンと酸の Discrepancy が認められたとしている. Olbe ら ${ }^{18)}$ は偽 食を与え迷走神経刺激状態にしたイヌにガストリンを静 注すると, ペプシン分泌が㧕制され, その程度はガスト リン量に比例すること、これに反し酸分泌増加すると 述べ，ガストリン刺激に扣ける主細胞と壁細胞の反応の 
不一致を認めている. 本研究です TG 刺激で, DU と GU を比較すると, ペプシン分泌では有意差がないのに 比へ，酸分泌では DU が GU に比べ有意に高い值を示 している.また RI 刺激では，ペプシン分泌と酸分泌は ともに DU の方が GU よりも有意に高い值を示してい る.すなわち各種刺激剤別にペプンン分泌量と酸分泌量 は異っている点があるとともに，一般に酸分泌では DU は高酸; GU は正酸ないし低酸19) という概念とは異な り，TG 刺激時のペプシン分泌量では DUと GU は有 意差がないという結果を得ている。この結果は高酸が特 徵の DU に比へ，正酸ないし低酸に战ける GU の発生 因子の重要な1つとして, ペプシンが役割を果している のではないかと想像される。

一方諸家の報告 ${ }^{20121}$ にもみられるよ5に，消化性潰痬 に批けるペプシン分泌量と酸分泌量を BPO と BAO, $\mathrm{MPO}$ と $\mathrm{MAO}, \mathrm{PPO}$ と $\mathrm{PAO}$ の関係からみると, す べて正の相関々係が得られ，ペプシン分泌量と酸分泌量 は密接な関係をるっていることは事実である。しかしな がらこの関係を術後胃についても検討してみると，その 相関々係の危険率は，RI 刺激時に特に高くなる。また 相関々係の直線の勾配にも変化が見られ，SPG，SPV士 D ともにペプシン分泌量は酸分泌量に比べ低下傾向を 示している.すなわち胃切除, 迷走神経切離という外科 的治療により，術前と同様に相関々係は保たれているる のの, ペプシン分泌量と酸分泌量では受ける影響が異な る。

ところでペプシン分必が迷走神経を介することは古く から知られて招り，また間接的に迷走神経を刺激するむ のとして，インシュリン投与による hypoglycemia，2Deoxy-D-glucose, sham feeding などが知ら礼ている2223) 24).また一方ペプシン分泌はヒスチミン，ガストリンな


本研究では DU に执いて TG と RI により受ける影響 がペプシン活性と酸度とでは異なり，さらに SPV 術後 もまたペプシン活性と酸度との受ける影響は異なってい た.しかも SPV による影響を両刺激凧でみると，ペプ シン分泌量が両刺激剤間に差がないのに対し, 酸分泌量 では RI 刺激後に著明な低下を認めた。

渡辺ら ${ }^{28)}$ は10例の DU K SPV を施行し,インシュ リン刺激前後のペプシン活性の変動を測定しているが, Hollander test ${ }^{29)}$ の結果を Ross \& Kay の criteria ${ }^{30)} に$ あてはめて, positive, late positive の症例ほどペプシン 滅少率は悪いとしている。とくに基礎ペプシン活性值は
術前とほとんど変らないが，基礎酸度が著明に減少する という違いを認めるとしている. Rosato ${ }^{31)}$ らは幹迷切 兼四門形成術を受けた DU の!1例に対し, 術前, 術後 にヒスタミン刺激を行い，刺激後 1 時間のペプシン減少 率は平均 $28 \%$ ，減酸率は平均 $31 \%$ であったと報告してい る. Cowley ら ${ }^{322}$ は10人の DU に幹迷切と幽門形成術を 施行し，その前後に carbachol 刺激を行った結果，ペプ シン分泌量と酸分泌量はとあに十分な減少が得られる が，ペプシンの減少率は酸の減少率に比べ20\%程度悪い と述べている. Tovey ら ${ }^{39}$ は迷切によるインシュリン刺 激でのペプシン活性は堿少するが，ヒスタミン刺激では ペプシン活性は変化なく，ペプシン分泌量では減少する とのべている.

以上のことから，ペプシンと酸は必ずしも平行するも のではなく，外科的治療により受ける影響もペプシンと 酸では異なっていることがわかる。

SPV の術後1 カ月のペプンン分泌は前述の如くであ るが，胃酸に関しては迷走神経切離により術後の時間的 経過で,インシュリン試験の結果が異なること，すなわ ち immediate test において Hollander test 陰性と判定 されたものが, delayed test において Hollander test 陽性となる事実に関する報告は多数見られる ${ }^{34) 35136)}$ 。こ のことは迷切後，時間の経過とともに，壁細胞の反応性 が亢進するのか，一過性の損傷を受けていた神経線維が 回復してくるのか, あるいはまた，迷走神経の再生，再 支配が起こるのか，その原因は不明である。またこれら の報告は幹迷切，または選迷切に関してのものであり， SPV に関しても Hollander test あるいは Ross \& Kay の基準で判定すべきであるか否かは問題であり，今回は 検討していない。しかしながら Hollander test 陽性例 がすぐに潰瘍再発に結びつかないとしても要注意であ ることに 異論はない，一方ペプシン 分泌す迷走神経を 介することから，迷切後のペプシン分泌量の如何によっ ては，ペプシン分泌が潰湯再発の重要な因子になるので はないかといらことは十分想像される. Limbosch ら ${ }^{37)}$ は21例の幹迷切の患者にインシュリンテストを行い, ぺ プシンと酸を測定した結果，ペプシン活性が酸度より早 く上昇し，迷切の判定に関してはペプシン分泌で判定し た方がよりよいのではないかと述べている．著者の研究 では, ペプシン分泌量と酸分泌量は SPV 後, RI 刺激 に抒いても正の相関々係にあり，術後の時間的経過によ る変化では両分泌量ともに術後 3 力月の方が術後 1 力月 よりも增加傾向を示しているが，有意差はなかった，今 
後注意を要すると思わせる。しかしながら Hirschowitz ら ${ }^{38}$ はイヌで Highly Selective Vagotomy を施行後 3 カ月毎に39カ月に渡り, ペプシン分泌量と酸分泌量を測 定した結果，ペプシン分泌量は全程過を通して殆ど回復

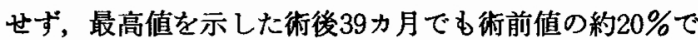
あったのに比べ酸分泌量は術後15力月頃より術前值の約 60\%に回復したといら興味ある報告をしている。この結 果がすぐにヒトにもあてはまるとは考兑ないが，ペプ シンと酸の解離を示すものであり，興味深いものであ る.

SPG は GU に対して幽門部を斜切し，幽門括約筋を 一部温存する勝見の考按の方法 ${ }^{6(7)}$ () 9 であるが，この方 法は元来，ダンピング症候群を予防する目的で考按され たもので，幽門部を一部温存するために当然，幽門粘膜も 一部残存するわけで，わが教室の伊奈 ${ }^{39}$ らは，午の残存 幽門腺が血清ガストリン值に拈よぼす影響について研究 した結果，SPG とB－I の間には血清ガストリン値に有 意差なく，従って SPG 施行による残存幽門粘膜の血清 ガストリン值に及ぼす影響は少ないとしている。また胃 内容排出関しては，臨床的にもわが教室の谷口らが, Gastroscintigram で SPG の有効性について報告してい るが，これらの結果をふをえて SPG がペプシン分泌に 如何なる影響を及ぼすかを検討してみたが，ペプシン分 泌量においても，SPG と B-Iには有意差がなく，ダン ピング症候群予防を目的とした SPG 術式はペプシン分 泌量および酸分泌量には決して悪影響をもたらしていな いことが認められた。

一方，潰瘍部位別に空腹時血清ガストリン值にはとく に差がないとの考光 ${ }^{40)}$ から潰瘍症例を一括して，基礎ぺ プシン活性と空腹時血清ガストリン值との関係をみた結 果, 負の相関々係が認められた，一般高酸の場合，酸 によるフィードバック機構が働いて，ガストリン分泌を 抑制する ${ }^{41}$ とされているが，その結果血清ガストリン值 が低値を示すようになり，さらに前述の負の相関々係か ら，ペプシン活性が高值を示す．すなわち高酸の場合は ペプシン活性も高い傾向があることになる．逆も同様で ある。しかしながらこれはガストリンのフィードバック 機構を介してみたペプシンと酸の関係であり，他の因子 を考慮に入れた場合，一概にはいいされない，ただこの 関係は血清ガストリン值が低い場合には，ペプシン活性 は高いことになり，潰痬発生の一因として，今後十分考 慮すべき点であると考えている。

GU ではペプシン分泌量と T $1 / 2 か ゙$ 正の相関々係を示
しているが，DU ではこの関係は得られない。これは GU は部位的に潰湯病変による狭窄は考えられないが， DU の場合，元々その内沿が比較的狭いうえに，潰瘍病 変による狭窄の硅度やスパスムスる考虑に入れなくては ならないために，GU と同様には考えられないすのと思 われる.

谷口ら ${ }^{137}$ の報告では，GU は Control よりる胃内容 排出が途延する傾向にあるとしており，また一般的に GU は正酸ないし低酸を示す．本研究結果より，GUで は胃内容排出の遅延するもの程ペプシン分泌量が増加す るといら関係を考号合せれば，胃酸が正酸あるいは低酸 でしかる，Control よりも胃内容の排出遅延がある症例 では, ペプシン分泌量が高い可能性があり，ひいてはこ れが潰場発生の一因となりらるとも推測される.

\section{$\mathbf{V}$ 結 緯}

消化性潰瘍の手術前後にバルーン付き胃管を使用して 胃液採取を行い，ペプシン活性を測定し，胃酸，空腹時 血清ガストリン值，胃内容排出時間との関連と消化性潰 瘍の外科的治療のペプシン分泌汶対する効果を検討し， 以下の結論を得た。

1. 胃切後の残胃では，バルーン付き胃管を噴門部よ り $4 \mathrm{~cm}$ 捜入することにより，ほぼ胃液全量の採取が可 能であり，上り正確な值が得られる。

2. 潰瘍患者のペプシン分泌量は Control 上りる高 く，また酸分泌量の高低にかかわらず，ペプシン分泌量 は高い

3. 消化性潰瘍患者において，ペプシン分泌量と酸分 泌量の間には相関々係がみられるが，DU では TG 刺 激に対するペプシン活性の反応は非常に弱い。

4. DU では RI 刺激に対する反応の速さは, ペプ シンの方が速く, 反応の程度は酸の方が強い.

5. SPV は RI 刺激時のペプシン活性には，あまり影 響を与兄ないが，酸度は有意に低下させる。また SPV のペプシン分泌量と酸分泌量への影響は, 術後 1 カ月と 3 カ月では有意差はない。

6. SPG と B-I の間には, ペプシン分泌量, 酸分泌 量共に有意差はない。

7. 消化性潰瘍患者において，基礎ペプシン活性の低 いものは，空腹時血清ガストリン值が有意に高い，逆も 同様である：

8. GU に扔いては胃内容排出の遅延するもの程, ペ プシン分泌量が有意汇高い。

稿を終るに臨み，䅂始ご指導ご校閱を賜った恩師勝見 
正治教授に，深甚なる謝意を表わすとともに，胃研究 班, 教室および和歌山労災病院外科の諸兄に深謝を表 す.

(なお，本論文の一部は第11回日本消化器外科学会総 会, 第64回日本消化器病学会総会にて発表した。)

\section{文献}

1）三好秋馬ほか：ペブシンの基礎と臨休．9 12 , 新宿書房, 東京, 1974.より引用.

2) Anderson, W., et al.: The protective action of an algal polyanion against experimentally produced peptic ulceration in the guinea pig. J. Physiol., 147: 52, 1959.

3) Barnes, W.A., et al.: Dextran Sulfate a New and Potent Antiulcer Agent. Amer. J. Surg., 113: 27-31, 1967.

4) 富沢㩒夫ほか：消化液の Dextran Surfateに及 䚾す影響について。衛生化学, 10：161-164, 1964.

5)行方正也ほか: Oligo 糖および単糖硫酸エステ ルの薬品的研究. Sucrose 硫酸エステルアルミ ニウムComplex の実験的消化性潰瑒抑制作用 について.薬学雑誌, 87：889-893，1967.

6) 岡村貞夫：幽門括約筋保存胃切除術に関する実 験的, 袘床的研究. 日外会誌, $74 ： 335-346$, 1971.

7)岡村貞夫ほか：われわれの幽門括約筋保存胃切 除術. 手術, 28:1053-1059, 1974.

8）勝見正治：幽門括約筋保存胃切除術に関する実 験的研究。日外会誌, 73：765-767，1972.

9) 前田和良：幽門括約笳保存胃切除後の残胃内容 排出に関す百研究。日消外会誌, 10：459469,1977

10）瀬田孝一ほか：バルーン付き胃管の考案. 医科 器械学, $46: 70-72,1976$.

11）上卜胃液測定法試案，日消誌，70：172一173, 1973.

12）谷口勝俊注か: ${ }^{99 m} \mathrm{Tc}$ sulfure colloid による新 しい検査一ガストロシンチグラムについて一。 Medical Postgraduates, $16: 432-435,1978$.

13）谷口勝俊：Gastroscintigram による 胃内容排出 機能検査（基礎的，噪床的㭘討）。日消誌，74： 1699-1707, 1977.

14) Anson, M.L., et al : The estimation of pepsin with hemoglobin J. Gen. Physiol., 16: 5963, 1932.

15）金抹泉洁か：臨床検査法提要。金原出版，東 京, 京都, 1975 .

16）及川司ほか：胃液㭘査よりみた消化性潰瘍手 術々式の検討。日本消化器病学会第64回総会講 演子報集，174-175，1978。

17）伊藤 健ほか：胃液酵素とPepsin 活性を中心 として，日消誌，69：744-745，1972.
18) Olbe, L., et al.: Effect of gastrin and histamin on vagally induced acid and pepsin secretion in antrectomized dogs. Acta Physiol. Scand., 72: 492-497, 1968.

19) Ishimori, A., et al.: Difference in secretory respons of the stomach to various gastric and duodenal ulcer. Gastroenterologia Japonica, 8: $353-362,1973$.

20)三好秋馬汪か：胃液分泌の病態と生理。4667, みづほ出版, 東京, 1976 .

21) Hirschowitz, B.I.: Secretion of Pepsinogen, Handbook of Physiology, Section 6, Alimentary canal vol. 2 ed. by Code F., American Physical Society, Washington, 1967.

22) Hirschowitz, B.I., et al.: Vagal gastric secretory stimulation by 2-Deoxy D-glucose. Amer J. Physiol., 209: 452-460, 1965.

23) Isenberg, J.I., et al.: Relation of gastric secretory response in man to dose of insulin. Gastroenterology，57: 395-398, 1969.

24) Duke, W.W., et al.: Vagal stimulation of gastric secretion in man by 2-Deoxy-D-glucose. Lancet, II. 871-876, 1965.

25）三好秋馬ほか：ペプシンの基碄と臨床. 99114 , 新宿書房, 東京, 1974.

26) Aagaard, P.: A comparison of the effect of pentagastrin and histamin on gastric pepsin secretion in man. Digestion, 3: 25-32, 1970.

27) Cooke, A.R.: Comparison of acid and pepsin outputs from gastric fistula dogs in response to histamine and related peptides. Gastroenterology, 53: 579-583, 1967.

28）渡辺英生汪か：各種消化性潰場と迷走神経切断 について。最新医学，29:2485-2492，1974.

29）村上忠重䚾か：胃迷切の臨床，207一231，金原 出版, 東京, 大阪, 京都, 1977 上り引用.

30) Ross, B., et al.: The Insulin Test After Vagotomy. Gastroenterololy, 46: 379-386, 1964.

31) Rosato, E.F., et al.: Effect of Truncal Vagotomy on Acid and Pepsin Response to Histamine in Duodenal Ulcer Subject. Ann. Surg., 173: 63-66, 1971.

32) Cowley, D.J.: Effect of truncal vagotomy on acid and pepsin: Response to a cholinergic drug in man. Gut, 13: 99-102, 1972.

33) Tovey, F.I., et al.: Effect of vagotomy on the gastric secretion of acid chloride and pepsin in response to an antral stimulus and to insulin and maximal histamine stimulation. Gut, 9: 659-666, 1968.

34) Masson, M.C., et al.: Postoperative insulin test: Failure to detect incomplete vgotomy in 
patients with high acid levels. Brit. J. Surg., 55: 865, 1968.

35) Gillepsie, G., et al.: The long term stability of the insulin test. Gastroenterology, 58: 625632, 1969.

36) Watkin, D.F.L., et al.: Changes in the postoperative insulin test in relation to recurrent duodenal ulcer. Gut, 12: 303-310, 1971.

37) Limbosch, J.M., et al.: Acid and Pepsin Secretion in Response to Insulin after Truncal Vagotomy in Man. Digestion, 4: 281-288, 1971.
38) Hirschowitz, B.I., et al.: Long-Term Effects of Highly Selective Vagotomy (HSV) in Dogs on Acid and Pepsin Secretion. Digestive disease, 22: $81-95,1977$.

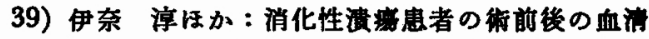
ガストリン反応と胃排出の闺連性. 日外会誌, 第78回日本外科学会総会号：210, 1978.

40) 長尾房大：外科 Mook. 12-18, 金原出版, 東 京, 大岅, 京都, 1978.

41) 藤田恒夫：ホルモン分汹のフィードハ,ク椣 一ガストリンの場合一医学のあゆみ，84：お住 えがき, 1973. 